\title{
LITERATUR REVIEW: PENERAPAN PIJAT KAKI DAN RENDAM AIR HANGAT CAMPURAN KENCUR TERHADAP EDEMA KAKI IBU HAMIL TRIMESTER III DI WILAYAH KERJA PUSKESMAS I WANGON, BANYUMAS
}

\author{
Tri Endah Widi Lestari ${ }^{1)}$ Melyana Nurul $W^{2)}$ Admini ${ }^{3)}$ \\ E-mail address: triendah331333@gmail.com
}

\begin{abstract}
Foot edema or swelling in the legs is found most in pregnant women in the third trimester, prioritizing the principles of care for mothers and babies to descrease discomfort, the need for prevention and appropriate care for pregnant women. The purpose of this article is to review some of the literature related to the application of foot massage and soak in warm kaempferia galanga L mixed water to reduce edema of pregnant women in the third trimester.

This article method is a form of analysis metadata research using literature review. The source used in the electronic database is EBSCO, and google scholar with the keywords foot massage, edema of the pregnant mother's feet/foot edema late pregnancy, soaking warm water, kaempferia galanga L as antiinflammatory. The article used is between 2009-2018, found 1 international journal and 14 national journals with 6main journals and 9 study supporting journals.

The results of foot massage and warm water soaked with kaempferia galanga $\mathrm{L}$ have not been applied in a similar manner, but from each treatment combined so as to reduce physiological edema of pregnant women in the third trimester. The discussion of the literature review of six journal articles can be combined and examined that intervening in foot edema in pregnant women naturally by using foot massage and soaking warm water mixed with Kaempferia Galanga L in a safe and effective intervention category to reduce edema of pregnant women.

The conclusion of this article was the application of foot massage therapy and warm water soaking the mixture of Kaempferia Galanga $L$ effective in reducing physiological foot edema in third trimester pregnant women who have not received any treatment.
\end{abstract}

Keywords: Foot Massage; Soak Warm Water; Kencur (Kaempferia Galanga L); Foot Edema; Late Pregnant Women.

1)2) Civitas Akademika Poltekkes Kemenkes Semarang.

3) Puskesmas Wangon I.

\section{Pendahuluan}

Kehamilan

mengalami perubahan fisiologis, dan psikologis. Perubahan fisiologis diantaranya perubahan organ reproduksi, sistem kardiovaskuler, pernafasan, ginjal, integumen, mukuloskeletal, neurologi, pencernaan, dan endokrin. Perubahan psikologis merupakan respon emosional yang terjadi akibat perubahan organ tubuh dan peingkatan tanggung jawab menghadapi kehamilan dan masa perawatan anak selanjutnya (Prawirohardjo, 2010).

Perubahan yang terjadi selama kehamilan membutuhkan suatu proses 
adaptasi baik fisik maupun psikologis. Proses adaptasi tersebut dapat mengakibatkan ketidaknyamanan fisiologis maupun patologis dalam pencapaian tujuan pelayanan kesehatan mengutamakan prinsip asuhan sayang ibu dan dan bayi untuk mengurangi ketidaknyamanan perlu adanya pencegahan dan perawatan yang sesuai untuk ibu hamil. Ketidaknyamanan selama kehamilan antara lain mual, muntah, ptialisme (salivasi berlebihan), keletihan, nyeri punggung bagian atas (nonpatologis), leukorea, peningkatan frekuensi berkemih (nonpatologis), nyeri ulu hati, flatulen, ligamentum teres uteri, nyeri punggung bawah (nonpatologis), hiperventilasi (nonpatologis), kesemutan, kaki bengkak dan sindrom hipotensi telentang (Irianti, 2014).

Ketidaknyamanan kehamilan trimester III meliputi sering buang air kecil sekitar 50\%, keputihan 15\%, konstipasi 40\%, perut kembung $30 \%$, edema (bengkak) kaki 20\%, kram kaki $10 \%$, sakit kepala 20\%, striae gravidarum $50 \%$, hemoroid $60 \%$, sesak nafas $60 \%$ dan sakit punggng $70 \%$ (Astuti, 2009 dalam(Rahmawati, Rosyidah, \& Marharani, 2016)), sedangkan pada peneltian(Famela, 2016)frekuensi berkemih 14\%, kram tungkai $3 \%$, nyeri punggung $48 \%$, sesak nafas $2 \%$, kesemutan $1 \%$ dan edema kaki $2 \%$, keluhan lainnya $30 \%$. Berdasarkan penelitian (Sukorini, 2017)sekitar 36 ibu hamil yang melakukan pemeriksaan pada trimester III $78 \%$ ibu hamil mempunyai keluhan seperti ibu hamil merasakan sakit punggung, kram atau kesemutan kaki, dan kaki bengkak yang sering terjadi di malam hari dan mengganggu kualitas tidur ibu hamil.

Edema kaki atau pembengkakan pada kaki ditemukan sekitar $80 \%$ pada ibu hamil trimester III, terjadi akibat dari penekanan uterus yang menghambat aliran balik vena dan tarikan gravitasi menyebabkan retensi cairan semakin besar (Coban \& Sirin, 2010). Edema kaki fisiologis menyebabkan ketidaknyamanan, perasaan berat, dan kram di malam hari (Coban \& Sirin, 2010) dalam (Nurhasanah, 2013). Edema bisa menunjukkan adanya tanda-tanda bahaya dalam kehamilan apabila edema dimuka atau di jari, sakit kepala hebat, penglihatan kabur sebagai akibat dari pre eklampsia (Purwaningsih, 2012 dalam (Nurhasanah, 2013)). Menurut Tiara (2012) dalam(Nurhasanah, 2013)), edema cukup berbahaya bagi ibu hamil karena bisa menyebabkan gangguan pada jantung, ginjal dan lain sebagainya sehingga menyebabkan organ tubuh tersebut tidak berfungsi sebagaimana mestinya.

Penatalaksanaan dari edema kaki adalah hindari mengenakan pakaian ketat yang mengganggu aliran balik vena, ubah posisi sesering mungkin, minimalkan berdiri dalam waktu lama, jangan dudukan barang diatas pangkuan atau paha akan menghambat sirkulasi, istirahat berbaring miring kiri untuk memaksimalkan pembuluh darah 
kedua tungkai, lakukan olahraga atau senam hamil, menganjurkan massage atau pijat kaki, rendam air hangat (Sinclair, 2009). Penggunaan intervensi non-farmakologis, pijat kaki dan rendam air hangat dicampur kencur merupakan salah satu intervensi non farmakologi yang dapat digunakan untuk ibu hamil. Pijat kaki ini merupakan terapi yang berupa pemijatan secara perlahan pada daerah kaki dilakukan 20 menit sehari selama 5 hari di daerah yang aman tidak menimbulkan kontraksi(Famela, 2016). Kemudian dilanjutkan dengan relaksasi menggunakan rendaman air hangat dicampur dengan kencur minimal 10 menit. Menurut Puthusseril (2006) dalam(Afianti \& Mardhiyah, 2017)foot massage atau pijat kaki mampu memberikan efek relaksasi yang mendalam, mengurangi kecemasan, mengurangi rasa sakit, ketidaknyamanaan secara fisik, dan meningkatkan kualitas tidur. Menurut (Coban \& Sirin, 2010)menunjukan bahwa pijat kaki efektif untuk menurunkan edema tungkai pada kehamilan lanjut. Terapi ini merupakan salah satu intervensi relaksasi efektif yang dapat digunakan pada edema yang terlihat dari mata kaki dan kaki pada usia kehamilan lebih dari 30 minggu.

Menurut (Flona, 2010)berendam dengam air hangat yang suhu 38 derajat selama minimal 10 menit dengan menggunakan aromatherapy mampu meredakan ketegangan otot dan menstimulus produksi kelenjar otak yang membuat tubuh merasa lebih tenang dan rileks. Terapi rendam kaki (hidroterapi kaki) membantu meningkatkan sirkulasi darah dengan mempelebar pembuluh darah sehingga lebih banyak oksigen dipasok ke jaringan yang mengalami pembengkakan(Chaiton, 2002 dalam (Wulandari, 2017). Raisanen (2010) dalam (Permady, 2015) menyebutkan ada enam keuntungan dari air hangat yaitu mengurangi stres, mendetoksifikasi, membuat tidur nyenyak, merelaksasikan otot dan meredakan sakit dan nyeri otot dan sendi, meningkatkan kerja jantung, meredakan sesak nafas. Penelitian oleh (P. Damarsanti, Anggraini, \& Setianingsih, 2018)rendam kaki dengan air hangat dapat menurunkan kecemasan pada ibu hamil trimester III.

Kencur sering digunakan sebagai obat tradisional salah satunya yaitu berkhasiat sebagai obat pengompres bengkak atau radang (Miranti, 2009). Pada penelitian Sulaiman (2007) dalam (Hasanah NA, 2011)menunjukan ekstrak air daun kencur mempunyai aktivitas antiinflamasi yang diuji pada radang akut yang diinduksi dengan karagenan, sedangkan (Hasanah NA, 2011)menyebutkan ekstrak rimpang kencur memiliki aktivitas antiinflamasi.

Tujuan studi ini untuk melakukan review pada beberapa literatur yag terkait tentang penerapan pijat kaki dan rendam air hangat campur kencur untuk 
mengurangiedema kaki ibu hamil trimester III.

\section{Metode Penelitian}

Jenis penelitian pada studi ini adalah metadata analisis dengan menggunakan literature review tentang penerapan pijat kaki dan rendam air hangat campur kencur

untuk mengurangi edema kaki ibu hamil trimester III. Sumber yang digunakan pada studi ini dari elektronik database yaitu EBSCO, dan Google Scholar dengan kata kunci foot massage/pijat kaki, edema kaki ibu hamil/foot edema late pregnancy, rendam air hangat, kencur sebagai antiinflamasi. Dalam studi ini artikel yang digunakan dalam kurun waktu antara tahun 2009-2018. Selama pencarian jurnal ditemukan 1 jurnal internasional di EBSCO, dan 20 jurnal nasional di google scholar yang terkait dengan kata kunci yang dicari. Selama pencarian jurnal tidak ditemukan jurnal yang sama dengan seluruh variabel dalam artikel ini. Kemudian dilakukan skrining terhadap jurnal tersebut, berdasarkan kriteria dan yang masih ada hubungan dengan variabel dalam artikel ini.Sehingga jurnal yang didapatkan sesuai dengan variabel yang akan direview dalam artikel ini.

Dari hasil skrining jurnal didapatkan 1 jurnal internasional dan 14 jurnal nasional. Dari 15 jurnal tersebut terbagi menjadi 6 jurnal yang ditelaah utama dan 9 jurnal sebagai pendukung literatur review. Data yang diperoleh akan ditelaah, kemudian disusun secara sistematis. Serta membandingkan dari setiap artikel penelitian atau literatur terkait. 


\section{Hasil dan Pembahasan}

Hasil literatur review pada artikel didapatkan bahwa pijat kaki dan rendam air hangat campur kencur belum ada yang menerapkan secara berasamaan, akan tetapi dari setiap perlakuan menunjukan dapat untuk mengurangi edema kaki. Sehingga dalam penelitian ini menunjukan bahwa pijat kaki dan rendam air hangat campur kencur dapat untuk mengurangi edema kaki pada ibu hamil trimester III, yang dilakukan pada 3 responden ibu hamil trimester III yang mengalami keluhan edema kaki fisiologis. Pijat kaki dilakukan selama 20 menit pada setiap kaki yang mengalami edema, dan dilanjutkan kaki direndam dengan air hangat yang sudah dicampur dengan kencur dengan ukuran 3 ruas jari yang sudah digeprek selama 10 menit. Perlakukan dilakukan berulang selama 5 hari pada setiap responden.

Berdasarkan dari beberapa penelitian yang telah dilakukakan, terdapat 6 artikel penelitian yang sesuai dengan penelitian ini. Menurut (Famela, 2016) dengan judul "Pijat Kaki Untuk Mengatasi Edema Kaki Fisiologis Ibu Hamil Trimester III Ny S umur 28 tahun G2P1A0 di BPM Hj Maunah Tambakagung klirong kebumen". Pada penelitian yang dilakukan perlakukan pada Ny. S yang sudah memenuhi kriteria inklusi dan eksklusi yaitu NY. S usia kehamilan 35 minggu (trimester III), belum pernah mengalami keguguran, dengan kehamilan normal atau tidak memiliki penyulit seperti preeklampsia, masalah kejiwaan, dan penyakit penyerta lainnya, memiliki keluhan edema kaki, kram di malam hari, dan belum mengetahui penatalaksanaan yang efektif untuk kaki yang bengkak (edema kaki) selama kehamilan. Pada hasil penelitian ini menunjukan responden merasa lebih nyaman karena edema kaki yang dialami dapat berkurang setelah mendapatkan pijat kaki dengan waktu 20 menit selama 5 hari pada edema kaki atau kaki yang bengkak. Simpulan penelitian yaitu pijat kaki terbukti efektif yang dapat menjadi alternatif pengobatan non farmakologis untuk mengurangi edema kaki pada ibu hamil trimester III.

Menurut penelitian (Coban \& Sirin, 2010) dengan judul "Effect $O f$ Foot Massage To Descrease Physiological Lower Leg Oedema In Late Pregnancy", memiliki tujuan yaitu untuk menilai efektifitas pijat kaki atau masase kaki dengan edema kaki fisiologis pada kehamilan lanjut. Metode penelitian yang digunakan Penelitian ini menggunakan randomized controlled trial, dengan 80 ibu hamil dibagi menjadi dua kelompok yaitu kelompok kontrol dan kelompok intervensi.Kriteria inklusi: kehamilan normal usia kehamilan > 30 minggu, edema terlihat pada pergelangan kaki dankaki, kehadiran di pusat perawatan dasar klinik I untuk perawatan kehamilan. Kriteria eksklusi: masalah kejiwaan, tidak hadir dalam acara di klinik I, preeklampsia, eklampsia, dan penyakit sistemik. Hasil pada penelitian ini menunjukan dari 80 responden, dibagi menjadi dua kelompok yaitu 40 kelompok kontrol dan 40 kelompok intervensi di kelompokan secara acak. Pada kelompok intervensi ditemukan 
kebiasaan selama kehamilan sebagai pemicu edema kaki sepertti berdiri terlalu lama, kenaikan berat badan berlebih, konsumsi makanan yang mengandung garam terlalu banyak, kurangnya konsumsi minum air putih dalam sehari. Pijatan dimulai dengan kaki dipegang dengan kuat, lalui usap seluruh bagian dari jari kaki sampai ke pergelangan kaki sepanjang bagian atas kaki meggunakan seluruh tangan, dan kembali di bawah kaki ke jari-jari kaki mengunakan lebih sedikit tekanan. Pemijatan dilakukan pada punggung kaki yang diarahkan ke tas, dan dari MP joint mengarah ke punggung kaki kemudian arahkan pemijatan keatas untuk mempelancar sirkulasi darah balik vena. Selama perlakukan pada kelompok intervensi, pengukurangan diambil pada pergelangan kaki kanan. Pijat kaki dilakukan pada kelompok intervensi selama 20 menit setiap hari dan dilakukan selama 5 hari berturutturut menunjukan perubahan yang signifikan pada kaki kanan (derajat edema kebih rendah) yang diberikan intervensi dari pada kelopon kontrol yang tidak diberikan intervensi. Simpulan penelitian ini yaitu Pijat kaki terbukti efektif dapat menurunkan derajat edema kaki fisiologis selama kehamilan lanjut, dengan cara dan daerah yang tepat.

Menurut penelitian (Edy Prananto, 2016) dengan judul "Pengaruh Masase Kaki Dan Rendam Air Hangat Pada Kaki Terhadap Penurunan Insomnia Pada Lansia", memiliki tujuan penelitian yaitu mengetahui pengaruh masase kaki dan rendam air hangat pada kaki terhadap penurunan insomnia pada lansia. Metode penelitian ini jenis kuantitatf dengan menggunakan quasi eksperimen. Sampel penelitian ada 15 lansia untuk kelompok intervensi, 15 lansia kelompok kontrol dengan menggunakan tehnik sampling yaitu simple random sampling, pengumpulan data menggunakan lembar observasi insomnia rating scale. Hasil penelitian menunjukan ada pengaruh masase kaki dan rendam air hangat pada kaki terhadap penurunan insomnia. Ratarata pengukuran pada kelompok intervensi sebesar16,33 pada pretest atau sebelum diberikan terapi menjadi 12,27 pada post test setelah diberikan terapi, sedangkan pada kelompok kontrol pretest sebesar 16,87 menjadi 16,13 saat post test. Hasil observasi menunjukan responden merasa lebih nyaman, rileks dan tenang setelah diberikan terapi masase kaki dan rendam air hangat, sehingga tidur lebih nyenyak. Simpulan: terapi masase kaki dan rendam air hangat berpengaruh terhadap penurunan insomnia.

Menurut penelitian (Purwadi et al., 2015) dengan judul "Pengaruh Terapi Conrast Bath (Rendam Air Hangat Dan Air Dingin) Terhadap Edema Kaki Pada Pasien Penyakit Gagal Jantung Kongestif', memiliki tujuan mengetahui pengaruh terapi contrast bath terhadap edema kaki pada pasien penyakit gagal jantung kongestif. Metode: penelitian menggunakan quasy experiment 
dengan pendekatan non equivalen control group design. Populasi sebanyak 18 orang gagal jantung yang mengalami edema kaki, dengan sampel 9 responden kelompok perlakuan, dan 9 orang kelompok kontrol. Hasil penelitian menunjukan bahwa Edema kaki di ukur menggunakan skala pitting edema dengan cara menekan area yang edema, dan mengukur kedalaman bekas tekanan. Terapi contrast bath dilakukan dengan merendam kaki dengan air hangat dengan suhu $36,6-43,3^{\circ} \mathrm{C}$ dan suhu dingin $10-20^{\circ} \mathrm{C}$. Dengan waktu perendaman pada air hangat 3 menit dan air dingin 1 menit. Pada kelompok intervensi perubahan penilaian menggunakan skala piting edema yaitu sebelum dilakukan perlakuan $6,11 \mathrm{~mm}$ dan setelah perlakuan adalah 3,44 mm. Pada kelompok perlakuan contrast bath mengalami perubahan signifikan pada edema kaki setelah diberikan terapi contrast bath dengan perbandingan waktu perendaman 3:1. Sedangkan pada kelompok kontrol penilaian pitting edema yaitu sebelum 5,78 $\mathrm{mm}$ dan sesudah 5,00. Simpulan penelitian yaitu ada perubahan yang siginifkan setelah dilakukan terapi contrast bath terhadap edema kaki pada pasien penderita penyakit gagal jantung kongestif.

Menurut (Hasanah NA, 2011) dengan judul "Analisis kandungan minyak atsiri dan uji aktivitas antiinflamasi ekstrak rimpang kencur (kaempferia galaga l)", tujuan penelitian yaitu mempelajari aktivitas antiinflamsi, kandungan dari rimpang kencur, kandungan minyak atsiri dengan menggunakan metode penelitian eskperimental di laboratorium. Hasil penelitian yaitu Antiinflamasi membuktikan pada ekstrak rimpang kencur dari kabupaten Subang yang dapat menginhibisi inflamasi yaituektrak kencur dosis $18 \mathrm{mg} / \mathrm{kg}$ bb sebesar $36,47 \pm 0,02$; $36 \mathrm{mg} / \mathrm{kg}$ bb sebesar40,07 $\pm 0,02$; dan

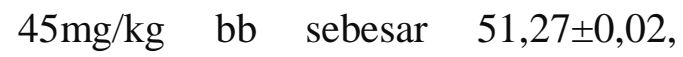
sedangkan dari kabupaten Sukabumi yaitu ekstrak kencur dosis $18 \mathrm{mg} / \mathrm{kg}$ bb sebesar 40,19 $\pm 0,04$; dosis $36 \mathrm{mg} / \mathrm{kg}$ bb sebesar 39,44 $\pm 0,06$; dan dosis $45 \mathrm{mg} / \mathrm{kg}$ bb sebesar 48,90 $\pm 0,05$. Pemberian ekstrak kencur dengan dosis 18, 36, dan $45 \mathrm{mg} / \mathrm{kg}$ bobot badan tikus, tidak menunjukan perbedaan dari asal daerah rimpang kecur. Kadar minyak atsiri ekstrak rimpang kencur dari kabupaten Subang lebih kecil yaitu sebesar $5,825 \%$, sedangkan dari kabupaten Sukabumi kadar minyak atsiri ekstrak rimpang kencur $14,41 \%$. Rimpang kencur dari kabupaten Sukabumi ataupun dari kabupaten Subang memiliki kandunganminyak atsiri yang sama yaitu 2,4,6 trimetil oktan, limonen dioksida, etilsinamat, etil pmetoksisinamat, dan asam etil ester 34metoksifeni -2-propenoat.Senyawa kimia dalam rimpang kencur yang berpengaruh antiinflamasi yaitu polifenol, kuinon, triterpenoid, tanin, flavonoid. Senyawa flavonoid merupakan senyawa yang berperan utama dalam antiinflamasi, dalam kandungan minyak atsiri. Kencur dari 
kabupaten Subang dan kabupaten Sukabumi sama memiliki aktivitas antiinflamasi. Simpulannya kencur sebagai tanaman obat efektif terhadap aktivitas antiinflamsi, tidak berpengaruh dari asal daerah.

Menurut penelitian (Manurung \& Sumiwi, 2017) dengan judul "Aktivitas Antiinflamasi Berbagai Tanaman Diduga Berasal Dari Flavonoid" memiliki tujuan untuk mereview tanaman yang mengandung flavoinoid. Metode penelitian yang digunakan artikel review ini menggunakan tinjauan pustaka dari berbagai jurnal yang berasal secara online. Terdapat 5 jurnal sebagai pustaka primer yaitu jurnal pengambilan dan pengujian penapisan fitokimia dan persentase inhibisi radang dari tanaman tersebut dengan metode pengujian sama. Proses pengujiannya yaitu dengan pengambilan dan pengujian metabolit sekunder dari tanaman, pengujian aktivitas antiinflamasi, dan analisis data secara statistik. Hasil penelitian pada artikel review ini menunjukan bahwa tanaman daun mahkota dewa, rimpang kencur, bunga dan daun asam jawa, kelopak bunga rosela merah memiliki aktivitas antiinflamasi, efek antiinflamasi yang ditujukan oleh presentasi inhibisi edema pada tanaman berbeda-beda tergantung pada dosisnya. Senyawa yang dapat memberikan aktivitas antiinflamsi yang terdapat pada semua tanaan tersebut yaitu senyawa golongan flavonoid. Simpulan yaitu kelima tanaman tersebut memiliki aktivitas antiinflamasi yang ditujukan pada adanya presentasi inhibisi terhadap edema. Presentase inhibsi edema terbesar pada tanaman kencur yaitu pada dosis $45 \mathrm{mg} / \mathrm{kg}$ bb menghasilkan inhibsi sebesar 51, 27\%, dan kelima tanaman tersebut memiliki senyawa flavonoid yang bekerja sebagai antiinflamasi.

Literature review yang sudah dipaparkan tidak semua artikel menjelaskan hasil penelitian yang sama persis dengan variabel pada artikel ini. Akan tetapi dari beberapa artikel tersebut dapat ditelaah dan dikombinasikan sehingga dapat digunakan pada artikel ini sesuai dengan dasar review jurnal penelitian.

Pada artikel diatasyang sudah ditelaah mekanisme pijat kaki yang dilakukan selama 20 menit selama 5 hari pada kaki yang mengalami pembengkakan atau edema kaki pada pergelangan kaki dan kaki terbukti efektif. Pemijatan dilakukan pada punggung kaki yang diarahkan ke atas, dan dari MP joint mengarah ke punggung kaki kemudian arahkan pemijatan keatas untuk mempelancar sirkulasi darah balik vena(Coban \& Sirin, 2010). Kegiatan manipulasi ini dilakukan dengan titik yang tepat sehingga efektif untuk mempelancar sirkulasi darah pada pembuluh darah balik vena(Famela, 2016). Dalam intervensi ini pijat kaki dapat memberikan stimulus rileks ke recticular activating system bekerja sebagai sistem kewaspadaan yang 
berada di batang otak teratas akan menurun dan dialihkan ke bulbar syncbronizing region (BSR) melepaskan serotoninyang dapat memberikan efek kantuk(Afianti \& Mardhiyah, 2017). Frekuensi waktu selama 20 menit ini terbukti efektif untuk mengurangi pembengkakan pada ibu hamil karena sentuhan atau gosokan atau pemijatan berulang akan menimbulkan peningkatan suhu diarea pemijatan yang dilakukan akan merangsang sensor saraf kaki sehingga terjadi vasodilatasi pembuluh darah dan getah bening yang mempengaruhi aliran darah meningkat, sirkulasi darah lancar, mengurangi bengkak dan dapat memobilisasi serat otot, tendon dengan kulit, dan menimbulkan efek relakasasi (Aditya, Sukarendra, dan Putu (2013) dalam (Afianti \& Mardhiyah, 2017).

Pada artikel yang sudah direview ada yang menunjukan masase kaki dan rendam air hangat berfungsi selain untuk mengurangi edema yaitu dapat memberikan efek relaksasi, nyaman, dan tenang sehingga dapat mengurangi insomia atau gangguan tidur. Mekanisme syaraf yang terjadi saat kaki di rendam air hangat yaitu plexus venousus dari rangkaian saraf ini stimulasi dilanjutkan ke cornu posterior dan ke medulla spinalis kemudian ke lamin I, II, III, radix doralis. Lalu ke ventrobasal thalamus dan berakhir di batang otak (daerah rafe) bagian bawah pons dan medula sehingga meninbulkan efek kantuk(Edy Prananto, 2016). Dari respon inilah responden akan merasa rileks, nyaman sehingga kualitas tidur meningkat (Raisanen, 2010 dalam(Permady, 2015).

Penelitian dalam artikel lain yang telah ditelaah bahwa rendam air hangat dan rendam air dingin efektif untuk mengurangi edema kaki. Suhu pada rendaman air hangat sangat mempengaruhi hasil dari terapi tersebut, suhu yang baik yaitu sekitar $36,6-43,3^{\circ} \mathrm{C}$, dan air dingin $10-20^{\circ}$ C(Purwadi et al., 2015). Temperatur yang digunakan dalam terapi air hangat diatas suhu tubuh karena pergantian panas dingin yang akan menstabilkan jantung dan aliran darah, sehingga tubuh akan lebih merasa nyaman. Akan tetapi dalam artikel ini hanya akan melakukan rendam air hangat setelah dilakukan masase kaki. Air hangat memiliki efek posisi terhadap kerja pembuluh darah dan saraf pada kaki. Saraf yang berada pada kaki menuju organ vital tubuh lainnya seperti menuju ke paru-paru, jantung, pankreas, dan lambung. Terapi rendam kaki atau hydrotherapy foot mampu meningkatkan sirkulasi darah karena terapi tersebutmemberikan efek mempelebar pembuluh darah (mekanisme vasodilatasi) sehingga oksigen lebih banyak yang masuk dalam jaringan yang mengalami pembengkakan, sehingga pembengkakan pada daerah kaki dapat berangsur berkurang (Chaiton, 2002 dalam (Wulandari, 2017).

Edema kaki ibu hamil terjadi pada saat kehamilan memasuki usia trimester III(Sukorini, 2017). Edema 
kaki fisiologis timbul adanya penimbunan cairan pada kaki dikarenakan penekanan uterus yang membesar sehingga menghambat aliran darah balik vena(Coban \& Sirin, 2010; Nurhasanah, 2013). Beberapa artikel review tersebut dipadukan untuk dapat ditelaah sesuai dalam artikel ini. Penelitian dalam artikel ini merupakan perpaduan dasar penelitian yang menyebutkan masase kaki dan rendam air hangat dapat mengurangi edema kaki.

Pada pengggunaan rendam air hangat dapat dipadukan untuk lebih efektif mengurangi edema kaki yaitu dengan kencur. Kandungan yang dalam kencur memiliki senyawasenyawa kimia yang dapat mengurangi edema atau inflamasi. Senyawa kimia dalam rimpang kencur yang berpengaruh antiinflamasi yaitu polifenol, kuinon, triterpenoid, tanin, flavonoid(Hasanah NA, 2011).Beberapa artikel review tersebut menyebutkan bahwa kandungan dalam kencur salah satunya yaitu flavonoid, yang dapat mengurangi edema atau inflamasi. Semakin besar dosis yang digunakan, akan semakin besar juga efek untuk antiinflamasi. Rimpang Kencur sebagai antiinflamasi dapat menghambat pelepasan serotonim dan dapat menghambat sintesis prostaglandin dari asam arakhidonat dengan cara menghambat kerja sikloksigenase(Hasanah NA, 2011).Penggunaanrimpang kencur dengan dosis $45 \mathrm{mg} / \mathrm{kg}$ bb dapat mengatasi edema atau inflamasi sebesar 51,27\%. Selain kencur tanaman obat yang mengandung flavonoid dapat digunakan untuk peradangan atau pembengkakan diantara yaitu daun mahkota dewa dengn dosis $0,5 \mathrm{~g} / \mathrm{kg}$ bb dengan efektif sebesar $27,35 \%$, daun ubi jalar dengan dosis $600 \mathrm{mg} / \mathrm{kg}$ bb dapat efektif sebesar 20,93\%, kelopak bunga rosela merah dengan dosis $410 \mathrm{mg} / \mathrm{kg}$ bb dapat efektif sebesar $31,93 \%$, dan asam jawa daun dan buah dengan dosis 0,2 $\mathrm{g} / \mathrm{kg} \quad \mathrm{bb}$ dapat efektif sebesar 47,9\%(Manurung \& Sumiwi, 2017). Dari literature reviewtersebut dapat diketahui kesempatan terbesar untuk antiinflamasi, dan mengurangi edema yaitu kencur, sehingga dalam penelitian ini untuk mengurangi edema digunakan kencur selain lebih mudah ditemukan, tanaman ini terbukti lebih efektif dari pada tanaman yang mengandung flavonoid lainnya.

Pada artikel ini penelitian dilaksanakan di wilayah kerja Puskesmas I Wangon Kabupaten Banyumas, yang dilakukan pada 3 responden yang memiliki keluhan edema derajat 2 sebanyak 2 orang dan derajat 3 sebanyak 1 orang. Perlakukan diberikan pada kedua kaki responden dengan memberikan pijat kaki selama 20 menit dan rendam kaki campur kencur dilakukan selama 5 hari. Intervensi pada kasus ini dilakukan sesuai dengan evidence base literature review diatas, pijat kaki dilakukan selama 20 menit pada setiap kaki yang edema dan dilakukan selama 5 hari pada titik yang tepat, dari rangsangan 
pijatan tersebut merangsang pembuluh darah dan getah bening untuk melakukan vasodilatasi sehingga cairan yang menumpuk pada pembuluh darah balik vena akan mengalir dengan lancardan didukung dengan rendaman air hangat yang dapat merangsang saraf dan pembuluh darah sehingga pembuluh darah akan mengalami pelebaran untuk menerima pasokan oksigen lebih banyak pada kaki yang mengalami bengkak. Dari kedua intervensi tersebut cairan yang terhambat pada pembuluh darah balik vena akan berkurang karena sirkulasi darah lancar, dan pasokan oksigen yang cukup. Akan tetapi untuk lebih mempercepat edema kaki dan tanpa efek samping yang terjadi dapat dikombinasikan dengan tanaman herbal yaitu kencur, selain sebagai untuk mengurangi bengkak dapat juga menghasilkan aromaterapi dari kandungan kencur yaitu minyak atisiri(Miranti, 2009). Selain minyak atisiri, kencur memilki senyawa flavonoid yang sebagai antiinflamasi(Hasanah NA, 2011). Aroma dari kencur sebagai aromaterapi akan ditangkap reseptor hidung yang kemudian merangsang ke otak yang mengendalikan dan berhubungan dengan perasaan (suasana hati dan emosi) lalu disalurkan ke hipotalamus sebagai pengatur dari sistem internal tubuh, sistem pengatur suhu tubuh, dan sistem pengatur aliran darah. Efek aromaterapi akan memberikan ketenangan, kenyamanan, mengurangi rasa sakit dan stres, dan memberikan
relaksasi(Maisi, Suryono, Widyawati, Suwondo, \& Kusworowulan, 2017). Aromaterapi pada rendaman air hangat dapat menstimulus kelenjar otak merangsang tubuh untuk rilek dan lebih tenang. Pada artikel ini menunjukan bahwa perlakukan tersebut efektif untuk menurukan edema kaki, aman dan memberikan efek relaksasi bagi ibu hamil sehingga keluhan edema kaki berkurang dan ibu merasa lebih nyaman, rileks, tenang dan tidur lebih nyenyak. Dari efek yang dirasakan tersebut, maka rendam air hangat juga dapat mengurangi kecemasan pada ibu hamil trimester III yang akan menghadapi persalinan ( $R$. A. Damarsanti, 2018). Dengan dasar review jurnal penelitian tersebut artikel ini dapat menunjukan efektifitasnya terhadap edema kaki fisiologis ibu hamil trimester III.

Dari hasil literature review terhadap enam artikel jurnal dapat di kombinasikan dan ditelaah bahwa intervensi pada edema kaki pada ibu hamil sebagai pengobatan non farmakologis atau secara alami dengan menggunakan pijat kaki dan rendam air hangat campur kencur dalam kategori intervensi yang aman dan cukup efektif untuk mengurangi edema kaki ibu hamil yang tidak mendapatkan pengobatan farmakologis.

\section{Simpulan}

Berdasarkan analisa yang telah dilakukan disimpulkan bahwa penerapan terapi pijat kaki dan rendam air hangat campuran kencur efektif 
dalam mengurangi edema kaki fisiologis pada ibu hamil trimester III yang belum mendapatkan pengobatan apapun.

\section{DAFTAR PUSTAKA}

Afianti, N., \& Mardhiyah, A. (2017). Pengaruh Foot Massage terhadap Kualitas Tidur Pasien di Ruang ICU. Jurnal Keperawatan Padjadjaran, 5(1).

Coban, A., \& Sirin, A. (2010). Effect of foot massage to decrease physiological lower leg oedema in late pregnancy: a randomized controlled trial in Turkey. International Journal of Nursing Practice, 16(5), 454460. doi: 10.1111/j.1440172X.2010.01869.X

Damarsanti, P., Anggraini, R., \& Setianingsih, S. (2018). Effect Soak Feet With Warm Water To Level Of Anxiety In Pregnant Women Trimester III Pegandon Kendal Public Health Center. Nurscope: Jurnal Penelitian dan Pemikiran Ilmiah Keperawatan, 4(1), 1-9.

Edy Prananto, A. (2016). Pengaruh Masase Kaki Dan Rendam Air Hangat Pada Kaki Terhadap Penurunan Insomnia Pada Lansia. Universitas Muhammadiyah Surakarta.

Famela, D. (2016). Pijat Kaki Untuk Mengatasi Edema Kaki Fisiologis Ibu Hamil Trimester III Ny S Umur 28 Tahun G2P1AO Di BPM Hj. Maunah
Tembakagung Klirong

Kebumen. Karya Tulis Ilmiah, Stikes Muhammadiyah Gombong.

Flona. (2010). Terapi Aromatic Mendongkrak Gairah Bercinta. Jakarta: Gramedia.

Hasanah NA, F. N., Ellin Febrina, Ade Zuhrotun. (2011). Analisis Kandungan Minyak Atsiri Dan Uji Aktivitas Antiinflamasi Ekstrak Kencur (Kaempferia Galaga L). Jurnal Matematika dan Sains, 16(3), 152.

Irianti, B. D. (2014). Asuhan Kehamilan Berbasis Bukti. Jakarta: Sagung Seto.

Maisi, S., Suryono, S., Widyawati, M. N., Suwondo, A., \& Kusworowulan, S. (2017). Efectiveness Of Lavender Aromatherapy and Classical Music Therapy in Lowering Blood Pressure in Pregnant Women With Hypertension Belitung Nursing Journal, 3(6), 750-756.

Manurung, N. R. M., \& Sumiwi, S. A. (2017). Aktivitas Antiinflamasi Berbagai Tanaman Diduga Berasal Dari Flavonoid. Farmaka, 14(2), 111-122.

Miranti, L. (2009). Pengaruh konsentrasi minyak atsiri kencur (Kaempferia galanga L.) dengan basis salep larut air terhadap sifat fisik salep dan daya hambat bakteri Staphylococcus aureus secara 
in vitro. Universitas

Muhammadiyah Surakarta.

Nurhasanah. (2013). Edema pada Ibu Hamil Trimester III Puskesmas Basuki Rahmad Kota Bengkulu. Stikes Bhakti Husada Bengkulu.

Permady, G. G. (2015). Pengaruh Merendam Kaki Dengan Air Hangat Terhadap Kualitas Tidur Lansia di Wilayah Kerja PUSKESMAS Astanalanggar Kecamatan Losari Cirebon Jawa Barat.

Prawirohardjo. (2010). Ilmu Kebidanan. Jakarta: YBP-SP.

Purwadi, I. K. A. H., Gipta Galih, W., Kp, S., Kep, M., KMB, S., Puspita, D., \& Ns, S. K. (2015). Pengaruh terapi Contrast Bath (Rendam Air Hangat dan Air Dingin) Terhadap Edema Kaki pada Pasien Penyakit Gagal Jantung Kongestif di RSUD Ungaran, RSUD Ambarawa, RSUD Kota Salatiga dan RSUD Tugurejo Provinsi Jawa Tengah: STIKES Ngudi Waluyo Ungaran.

Rahmawati, N. A., Rosyidah, T., \& Marharani, A. (2016). Hubungan Pelaksanaan Senam Hamil Dengan Ketidaknyamanan Ibu Hamil Trimester Iii Di Bidan Praktek Mandiri Supadmi, Kunden Bulu, Sukoharjo. INVOLUSI Jurnal Ilmu Kebidanan (Journal of Midwifery Science), $7(12)$.
Sinclair. (2009). Buku Saku Kebidanan. Jakarta: EGC.

Sukorini, M. U. (2017). Hubungan Gangguan Kenyamanan Fisik Dan Penyakit Dengan Kualitas Tidur Ibu Hamil Trimester III. The Indonesian Journal of Public Health, 12(1), 1-12.

Wulandari, P. (2017). Effect Foot Soak Using Warm Water Mixed with Salt and Lemongrass to Decrease Pressure in Hypertension Patients in the Podorejo Ngaliyan. Jurnal Keperawatan, 7(1). 